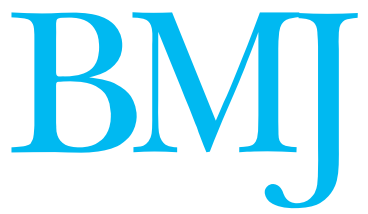

\title{
NHS foundation trusts
}

\author{
The Healthcare Commission's review offers something for both proponents \\ and detractors
}

News p 68

BMJ 2005;331:59-60
$\mathrm{T}$ The first foundation trusts in England and Wales were established on 1 April 2004. These trusts are a cornerstone of the government's policy to decentralise decision making in the NHS. ${ }^{1}$ To proponents, foundation trusts are setting the NHS free from the yoke of central government. ${ }^{2}$ To opponents, however, these trusts represent a kind of back door privatisation which may destabilise the NHS and introduce a two tier service. ${ }^{3}$ The NHS inspectorate, the Healthcare Commission, has now reviewed the first 20 foundation trust. It published its report this week. ${ }^{4}$

Foundation trusts are not for profit public benefit corporations with extra freedoms to borrow capital, sell assets, retain surpluses in each year, and to develop their own systems for managing and rewarding their staff. These trusts have to meet national targets and standards like the rest of the NHS, but they are free to decide how to achieve this. They are not subject to directions from the secretary of state for health or to performance management by strategic health authorities and the Department of Health. There are now 32 foundation trusts, all converts from the previous model of NHS trusts, and all overseen by a new independent regulator called Monitor. ${ }^{5}$

Although foundation trusts have their own regulator, the government asked the Healthcare Commission to review the trusts' performance: this was at least partly an attempt to mollify critics' concerns. The commission's remit was tightly drawn. It covered the impact of trusts' new status on access to and quality of services, on the engagement of both staff and the local community in the work of the trust, on relationships within local health communities, and on governance. The commission was not asked to make judgments on the value of the policy on foundation trusts or on whether it should continue or be extended.

\section{Managers are mostly happy ..}

The commission found that the managers of foundation trusts welcomed their new freedoms. In particular, directors reported improvements that included greater ability to plan ahead and to set priorities for investment; more confidence in financial management; and faster decision making and funding for developments in services. However, some of the promised freedoms have not lived up to managers' expectations. Foundation trusts have been limited in their ability to borrow money by their independent regulator through a "prudential borrowing code." Initially, this limited borrowing to only $10 \%$ of trusts' total assets, although this restriction has since been eased by Monitor. Trusts have also railed against the "private patient cap," which states that they can earn no more from private patients now than they did before becoming foundation trusts, a restriction that is not applied to other NHS trusts that are still managed by the government.

\section{... but little has changed for patients}

Foundation trusts have made good progress in reducing waiting times for NHS care, but not more quickly than the acute trusts that have not achieved or sought foundation status. The review found little evidence of any major improvement in the quality of care, with some measures showing improvement and others deterioration. Again, the review found a similar picture for NHS trusts as a whole. Furthermore, interviews with clinical staff suggested that the move to foundation trust status had not changed the way in which clinical care was provided, a finding corroborated by staff in primary care trusts.

The intended radical changes in the governance of foundation trusts have taken place. Foundation trusts recruit members (drawn from local residents, patients, and staff) who elect governors to represent their interests in the management of the trust. Boards of governors in each trust have powers to-among other things-appoint, dismiss, and remunerate the chairperson and non-executive directors; to approve the appointment of the chief executive; and to be consulted on forward planning by the board of directors.

Membership among patients and the public has continued to rise, and elections for governors to represent constituencies of patients and the public have generally been competitive, with most contested by more than one candidate. Nevertheless, critics of the new arrangements for governance have pointed out that the registered memberships are but a small fraction of the eligible population. ${ }^{6}$

Governors have complained about a lack of clarity in their role, and foundation trusts seem to vary in the extent to which they value the new arrangements for governance. Important changes to the boards of directors have also occurred. Non-executive directors no longer have to represent the views of local communi- 
ties (that is now the governors' job), and boards are particularly seeking non-executive directors with skills such as finance, business, and marketing. Some boards now meet in private, raising concerns over transparency. If the role of the governor is not clarified and strengthened, foundation trusts risk becoming less accountable to the public. ${ }^{7}$

One concern about the advent of foundation trusts was that they might threaten cooperation between healthcare organisations serving local communities, ${ }^{3}$ but the review has found no evidence of this. Current relations between organisations are usually determined strongly by past relations. Where trusts have worked well with local organisations previously, relations have remained good; where they were poor, they have worsened. In some cases foundation trusts have withdrawn from local planning meetings. Clinical relationships, however, have remained largely unchanged, with NHS consultants in foundation trusts still belonging to cross organisational clinical networks.

Foundation trusts have arrived at a time of other far reaching developments in NHS policy, such as a new payment system for hospitals and a new contract for consultants. These other factors have created a turbulent environment for the early foundation trusts. In a carefully worded criticism of the Department of Health's management of policy, the Healthcare Commission calls for better coordination of national policy and for the likely impact of new arrangements to be assessed before implementation.

\section{Something for everyone, but no clear message}

For those hoping to reach a clear judgment about the usefulness of foundation trusts, this week's report by the Healthcare Commission is bound to be something of a disappointment. The review offers something for both proponents and detractors of this policy. Foundation trusts have, not yet at least, declared wholesale independence from local partnerships in the NHS. Nor have they ushered in a two tier service. Most importantly, they do not seem to have offered any particular advantage to patients. A poor return, perhaps, for so much effort and expense.

Have foundation trusts been afforded the wrong freedoms, or insufficiently powerful ones? Or have they not yet reached maturity? With these questions in mind, the Healthcare Commission ends its report with a call for a further review in two years. In the meantime, however, the rumbling row over foundation trusts is likely to continue.

Richard Q Lewis fellow in health policy

King's Fund, London W1G 0AN

(R.lewis@kingsfund.org.uk)

Competing interests: RQL was an unpaid member of the Healthcare Commission's foundation trust review advisory panel and offered advice on the analysis and presentation of data.

1 Secretary of State for Health. The NHS improvement plan: putting people at the heart of public services. London: HMSO, 2004. (Cm 6268.) www.dh.gov.uk/assetRoot/04/08/45/22/04084522.pdf (accessed 1 Jul 2005).

2 Department of Health. A guide to foundation trusts. London: Department of Health, 2002. www.dh.gov.uk/assetRoot/04/02/99/90/04029990.pdf (accessed 1 Jul 2005).

3 Unison. Seven reasons why UNISON is opposed to Foundation Trusts. 2003. www.unison.org.uk/acrobat/B799.pdf (accessed 1 Jul 2005).

4 Healthcare Commission. Healthcare Commission's Report on the review Healthcare Commission. Healthcare Commission's Report on the review
of NHS foundation trusts. 2005. www.healthcarecommission.org.uk of NHS foundation
(accessed 5 Jul 2005).

5 NHS foundation trusts. www.dh.gov.uk/PolicyAndGuidance/ NHS foundation trusts. www.dh.gov.uk/PolicyAndGuid
OrganisationPolicy/SecondaryCare/NHSFoundationTrust/fs/en (accessed 1 Jul 2005)

6 Klein R. The first wave of NHS foundation trusts. BMJ 2004;328:1332.

7 Lewis R. Governing foundation trusts-a new era for public accountability. London: King's Fund, 2005. www.kingsfund.org.uk/pdf/ governingfoundationtrusts.pdf (accessed 1 Jul 2005).

\section{Epilepsy and driving}

\section{Regulations in the European Union need harmonisation as well as greater flexibility}

$\mathrm{T}$ The lack of driving privileges is one of the major concerns of people with epilepsy. Seizures undoubtedly represent a potential source of accidents and injuries, and this justifies limitations on driving for people liable to epileptic seizures. Convincing evidence shows that in the absence of seizures (with or without treatment), the risk of accidents and injuries is clearly decreased and tends to be close to that of the general population. ${ }^{12}$

Unfortunately, the variability of published reports on risk has led to differing regulations for a driving licence among the members of the European Union and elsewhere in the world, ${ }^{3}$ with each jurisdiction developing and enforcing its own regulations on epilepsy and driving. The European Council Directive 91/439/EEC on driving licences reports, "a licence may be issued or renewed subject to an examination by a competent medical authority and to regular medical check-ups. The authority shall decide on the state of the epilepsy or other disturbances of consciousness, its clinical form and progress (no seizure in the last two years, for example), the treatment received and the results thereof." ${ }^{\prime 4}$ For commercial driving it states "driving licences shall not be issued for applicants or drivers suffering or liable to suffer from epileptic seizures or other sudden disturbances of the state of consciousness."

\section{Rules vary from state to state}

In the European Union, some member states, including the United Kingdom, require a one year period of freedom from seizures before granting or renewing a driving licence although most require a two year period. More variation exists about exceptions where people with active epilepsy may drive (for example, seizures during sleep, myoclonic 